\title{
Institutional Strengthening System and Regulations in the Development of Bongkasa Pertiwi Tourism Village, Badung Regency
}

\author{
Putu Adi Suprapto ${ }^{1, *}$, Ni Luh Ayu Kartika Yuniastari Sarja ${ }^{2}$ \\ ${ }^{1}$ Department of Accounting, ${ }^{2}$ Department of Tourism \\ Politeknik Negeri Bali \\ Badung, Indonesia \\ *adisuprapto@pnb.ac.id
}

\begin{abstract}
Bongkasa Pertiwi Village was designated as a tourism village starting in 2010 which is a step from Badung Regency in responding to challenges in the world of tourism. Its status as a tourist village for the last $\mathbf{1 0}$ years has grown several supporting tourism businesses such as rafting on the Ayung River, swing with river views and beautiful panoramas, paintball, ATV riding, homestay, and cycling. The existence of this business has not optimally provided a direct economic impact, such as the contribution to Bongkasa Pertiwi Village. On a different side, this business growth also raises various unresolved problems, such as unhealthy business competition that causes market prices to collapse, not having business licenses, labour protection, especially in determining salaries that are not following the Regency Minimum Wage and paying taxes. One way to overcome this problem is to form a Holding Company that can support several Small and Medium Enterprises (SME) in Bongkasa Pertiwi Village. The purpose of this research is to formulate an ideal institutional system, especially to vitalize the role of VillageOwned Enterprises (BUMDesa) in the existing economy in Bongkasa Pertiwi Village. The method of implementing this activity is to find supporting data through observation, interviews, and focus group discussions with related parties such as the Village Head, the Head of BUMDesa, the Head of the Bongkasa Village Tourism Awareness Group (Pokdarwis), the Village Facilitator of Badung Regency and the tourism business owners in Bongkasa Pertiwi Village. This is done to solve problems to get common ground on two main problems, such as the absence of significant contributions to the village from existing tourism businesses and the problems that exist at the SME level in fact have caused several communications between villages and existing SMEs. Then held several meetings such as the implementation of a focus group discussion. After that, it was decided to make BUMDesa Mandala Sari as the holding company of several existing businesses. BUMDesa Mandala Sari has the authority as a holding company for the businesses it shelters by Article 24 of the Regulation of the Minister of Villages, Development of Disadvantaged Areas, and Transmigration Number 4 of 2015. The results of this research were marked by the formation of a cooperation agreement between BUMDesa Mandala Sari and 12 SMEs, on 28 August 2020. In the agreement, it was agreed that BUMDesa is used as a
\end{abstract}

holding company as a step in increasing the productivity and income of SMEs and making efforts to solve existing problems. In exercising its authority as a holding company, BUMDesa can carry out various efforts such as setting the basic price of products to prevent unfair competition that has occurred so far, seeking licenses for the businesses it shelters so that they can directly protect local workers who work for SMEs that are under shade BUMDesa. It is hoped that with this protection, local workers can receive income according to the minimum standard in Badung Regency. Furthermore, BUMDesa Mandala Sari can carry out various forms of empowerment such as training for tourism actors to improve service quality and increase financial reporting in each SME. On the other hand, BUMDesa has also agreed to obtain contributions from SME and BUMDesa can sell products sold in village shops owned by BUMDesa to the SME it shelters, The supply of vegetables and rice has been supplied by farmers in the village environment, so it can be said that the existence of BUMDesa Mandala Sari can indeed be considered beneficial for the residents of Bongkasa Pertiwi Village.

Keywords-BUMDesa, tourism village, regulation, holding company

\section{INTRODUCTION}

Tourism management currently developing in Bali Province is the development of the tourism sector based on individuals. Individually based, which is meant here, of course, cannot be separated from the indicator of people who have a large capital. The construction of hotels, restaurants, playgrounds, and other tourism businesses has only been carried out by capital owners and business entities in the form of PT. During the economic progress of tourism before COVID 19 hit, Bali is not only a visiting destination for world tourists but a destination for doing business by major world investors.

The current government's commitment to prioritizing the village as the foothold of national development must of course be used as the best momentum from the village government in responding to these challenges. Some strategic steps should be taken so that the village will not only become spectators of the 
tourism activities in the village but become creators and executors of the existing tourism economy. This is of course in line with the existing economic system in Indonesia which puts forward the principles of democracy and Pancasila in its implementation. In the People's Economic System, the community plays an active role in economic activities, while the government creates a healthy climate for the growth and development of the business world [1]

Increasing the ability of the community to control the running of the economy is the goal of the Indonesian nation, which is in line with the Indonesian national identity itself. Siding with the people's economy is an important aspect that must be used as the basis for realizing justice and economic democracy by the mandate of the Indonesian Constitution [2].

Badung Regency has made various efforts in developing tourism villages in the North Badung area to maintain the amount of Regional Original Revenue (PAD). The aim of this effort is to create integration and balance between the South Badung Region and the North Badung Area. Based on the indicators of the availability of tourism accommodation facilities, it can be said that the South Badung area is growing rapidly, especially in the tourism areas of Kuta, Jimbaran and Nusa Dua. In fact, due to the perceived imbalance and increasingly limited land factors, in 2011 the Governor of Bali issued a Decree of the Governor of Bali No. 570/1665 / BPM concerning the Temporary Suspension of Investment Registration for the Tourism Accommodation Services Business Sector [3], particularly in the South Bali Region. The North Badung area still has the potential to be developed into a tourism area when viewed from the natural factors that are still beautiful and the potential of local culture that can attract tourists to visit the area. The potential of the tourism sector plays a very important role in the development of an area [4]. Besides that, tourism is important as a source of income for an area [5]. The development of tourism in an area can bring many benefits both from an economic, social and cultural perspective [6].

Bongkasa Pertiwi Village, Abiansemal District is one of the tourism villages that has various potentials to be developed. This tourism village can be a place to stay, do activities, and enjoy the natural panorama for tourists who visit. Based on observations, information was obtained that the Badung Regency government for 2020 budgeted assistance for homestay development as one of the policies in the development of the Bongkasa Pertiwi tourism village. Before the Covid-19 pandemic, in Bongkasa Pertiwi Village we could easily find foreign tourist visits and tourism activities such as rafting on the Ayung River, swing with river stretches, and beautiful panoramas, paintball, ATV riding, homestay, and cycling. However, until now, it is felt that the existence of this business has not had a significant impact on the economic development and progress of the Bongkasa Pertiwi Village community.

The existence of Village-Owned Enterprises which was established in 2017 in accordance with the Bongkasa Pertiwi
Village Regulation Number 5 of 2017 concerning the Establishment and Management of Village-Owned Enterprises (BUMDesa) [7] which until now has not had the power in the tourism business it supports. Weaknesses in authority and institutional obscurity in the aspect of tourism management are the main factors that make BUMDesa only as spectators in the activity of tourism. In fact, from the initial data obtained, there are many problems that occur in the field, such as some business owners having difficulty obtaining business permits, unfair price competition, and neglected fulfilment of labour rights. It is felt that the weaknesses in the institutional and regulatory fields in the management system need to be resolved to realize the objectives of developing the tourism village. The preparation of a study on the institutional and regulatory strengthening system in the development of the Bongkasa Pertiwi Tourism Village of Badung Regency is one of the solutions offered in realizing the ideal form of management and development of tourism activities in one of the villages in the North Badung Region.

\section{METHODS}

This research consists of the stages of data collection, literature study and data analysis, focus group discussion, drawing conclusions, and recommendations. This research took one of the villages in Badung Regency as a case study, namely Bongkasa Pertiwi Village, Abiansemal District. The type of data in this study is in the form of qualitative data, namely data in the form of information and explanations related to the potential and problems of the aspects of tourism management by Bongkasa Pertiwi Village. The data collection technique in this study used observation at the research location to find the necessary data, interviews were conducted 6 times in a row in May 2020 with parties directly related to this research such as the Village Head, Village Secretary, BUMDesa Chair, Pokdarwis Chair. Village Facilitator of Badung Regency and Chairperson of the UKM Association in Bongkasa Pertiwi Village. The results of the interview indicated the problems being faced, namely problems in business management and problems with direct contributions to the village. In addition, literature studies that are relevant to this research are carried out, namely books and related laws and regulations [8]. Finalization of the data obtained was then taken to a focus group discussion (FGD) which was held on June 23, 2020, with existing stakeholders such as village officials, BUMDesa administrators, Pokdarwis, Badung District Village Facilitators and all SMEs involved where the number of participants was 20 people. The result of this FGD was that BUMDesa was agreed as the holding company of 12 SMEs in Bongkasa Pertiwi which was then stated in the cooperation agreement. The data analysis technique used is descriptive qualitative, namely by providing narrative and meaning to qualitative data and information. The final stage is drawing conclusions and providing recommendations to provide an overview or description of the Institutional and Regulatory Strengthening System in the Development of Bongkasa Pertiwi Tourism Village, Badung Regency. 


\section{RESULTS AND DISCUSSION}

\section{A. Overview of Bongkasa Pertiwi Village}

Bongkasa Pertiwi Village is in Abiansemal District, Badung Regency, Bali, with an area of 157 hectares and a population of approximately 2,504 people. Based on data collection, Bongkasa Pertiwi Village is an area that includes a plateau with an altitude of $312 \mathrm{~m}$ above sea level, a humid tropical climate with rainfall of almost $2000-3000 \mathrm{~mm} / \mathrm{six}$ months with an average temperature of $30-35^{\circ} \mathrm{C}$. Bongkasa Pertiwi Village has three banjars, namely the Karang Dalem I, Karang Dalem II and Tegal Kuning banjar. The potential of villages in Bongkasa Pertiwi Village that can support the sustainability of the tourism and agricultural sectors which are continuously being developed include the following:

1) Natural panorama: The potential of Bongkasa Pertiwi Village, which has a beautiful natural panorama, provides space for tourism players around the village to develop swing, cycling, ATV, homestay, and paintball businesses. The swing business in this area has exceeded 5 businesses, and the one most known to tourists is the Bali Swing. Of course, this business has absorbed several local workers who come from Bongkasa Pertiwi Village itself, which results in the profession of the majority of the people being involved in the world of tourism.

2) Ayung river: Bongkasa Pertiwi Village passes through the Ayung River, one of the oldest and longest rivers in Bali. The Ayung River has a fairly heavy flow of water, giving rise to rafting activities for tourists. Rafting activities in Bongkasa Pertiwi Village before Covid-19 are the main attraction besides swinging when foreign tourists visit Bongkasa Pertiwi Village. This river also meets irrigation needs for agriculture, plantations, and livestock.

3) Agricultural area: Bongkasa Pertiwi Village still has 76 hectares of productive rice fields. This farming activity indirectly also makes Bongkasa Pertiwi Village an attractive landscape for tourists. The rice yields from the operation of agriculture in this village are allegedly able to make Bongkasa Pertiwi Village become a rice-independent village.

4) Culture and customs: The majority of the people in this village are Hindu. Traditions and cultures are still preserved from generation to generation. The village of Bongkasa is likened to one of the sources of art in Bali, as evidenced by the number of art maestros who come from this village, one of which is Ki Dalang Tangsub, the founder of Bongkasa Village which is known for the emergence of geguritan in Bali, and one of the famous ones is "Eda Ngaden Awak Bisa ". Another unique culture is the sambuk war. The Sambuk war (coconut fiber) is a tradition of the Sekaa Truna Budhi Pawerti Stiti which is carried out on the night of pangerupukan in order to welcome Nyepi. Usually, the sambuk war is held at 00.00 Central Indonesian Time, after the ogoh-ogoh procession is finished. This sambuk war has meanings, among other things, to maintain togetherness among youth members, learn to work together among youth members, increase the spirit of courage for each youth, and entertainment for youth.

5) Historical building: Bongkasa Pertiwi Village has many buildings in the form of ancient temples with distinctive architecture that have their respective histories and religious ritual activities. The ancient buildings that have historical value in Bongkasa Pertiwi Village are Pura Batu Megong, Pura Dalem, Pura Puseh-Desa, Pura Penataran, Pura Dalem Kayangan, and Pura Masceti. The panorama of rice fields with its subak system, the uniqueness and architectural beauty of the temple buildings in the village are worthy of being a tourist attraction.

\section{B. Establishment of the Bongkasa Pertiwi Tourism Village}

The enormous potential of Bongkasa Pertiwi Village must be managed properly by the Bongkasa Pertiwi Village itself and of course the benefits can be felt directly by the Bongkasa Pertiwi community. However, there have been various problems which have not been resolved completely. Community participation in making important decisions in the village is accommodated in village meetings. This is a step in improving the quality of life and life and the welfare of society as well as reducing poverty [9]. The determination of Bongkasa Pertiwi Village as a Tourism Village in 2010 which then followed up with the formation of BUMDesa Mandala Sari in 2017 is the initial framework for the Village in regulating and establishing an institutional system in the management of its tourism village.

The regulation of tourism villages is contained in the Regulation of the Minister of Tourism and Culture of the Republic of Indonesia Number: PM.26 / UM.001 / MKP / 2010 concerning the National Program for Community Empowerment for Independent Tourism (PNPM) through Tourism Villages [10]. Tourism Village is a form of integration between attractions, accommodation and supporting facilities that are presented in a structure of community life that is integrated with the prevailing procedures and traditions. Tourism villages are generally in the form of rural areas that have several special characteristics, so that they are worthy of being a tourist destination. In this area, people still have traditions and culture that are still relatively authentic. Fandeli [11] more comprehensively describes a tourism village as a rural area that offers an overall atmosphere that reflects the authenticity of the village, both in terms of socio-cultural life, customs, daily activities, building architecture, and village spatial structure, as well as potential that can be developed. as a tourist attraction, for example attractions, food and drink, souvenirs, lodging, and another tourist needs.

The determination of Bongkasa Pertiwi Village as one of the tourism villages in Badung Regency is explicitly stated in the provisions of Article 8 of Badung Regent Regulation Number 47 of 2010 concerning the Designation of Tourism Village Areas in Badung Regency [12]. In the preamble to the Badung Regent Regulation, it is then explained that to realize 
sustainable tourism development, it is necessary to diversify tourism objects that are oriented towards improving community welfare, preserving cultural arts and being environmentally friendly. For this reason, it has become a necessity for Bongkasa Pertiwi Village to develop existing tourism facilities to pay attention to the existing aspects of ecology and authentic culture. This is in line with one of the policies established by the Bali Provincial Government in strengthening the tourism sector in Bali through the Bali Provincial Regulation Number 2 of 2012 regarding Balinese Cultural Tourism. Based on the provisions of Article 1 point 14, it is stated that: "Balinese Cultural Tourism is Balinese tourism based on Balinese Culture which is animated by the teachings of Hinduism and the Tri Hita Karana philosophy as the main potential by using tourism as a vehicle for its actualization, so that a dynamic reciprocal relationship is created. between tourism and culture which makes them develop synergistically, harmoniously and sustainably to provide prosperity to the community, cultural and environmental preservation [13]".

\section{BUMDesa as a Holding Company}

The formation of BUMDesa Mandala Sari was marked by the enactment of the Bongkasa Pertiwi Village Regulation Number 5 of 2017 concerning the Establishment and Management of Village-Owned Enterprises. The establishment of BUMDesa [7] aims to drive the village economy and explore local potential to be utilized for the welfare of the local community. To achieve this goal, BUMDesa establishes business units, including the Water Management Business Unit, Waste Transportation Service Unit, Shop Business Unit and Tourism Business Unit.

The benefits of the tourism business in Bongkasa Pertiwi Tourism Village have been felt so far, especially by tourism actors and workers who work in tourism rafting businesses on the Ayung River, swing, paintball, ride All-Terrain Vehicles, trecking and cycling. Based on the results of the interviews that have been conducted, the tourism activities that have been growing and developing in Bongkasa Pertiwi Tourism Village not only provide the positive benefits mentioned above, but also cause several problems. The decline in environmental quality has not been felt in the existing tourism activities. The problems that arise based on the results of the focus group discussion include the occurrence of price imbalances in the rafting business which causes unfair competition between existing rafting businesses; The aspect of fulfilling labour rights has not been felt by the members of the Bongkasa Pertiwi community who work in their existing business premises. This problem is a derivative of several businesses that do not have a license; The role of the village in business management in the village environment is still weak.

Based on Article 24 of the Regulation of the Minister of Villages, Development of Disadvantaged Areas and Transmigration Number 4 of 2015 [14], states that:
- "BUMDesa can run a joint venture (holding) as the parent of business units developed by the Village community, both on a local Village scale and in rural areas.

- Business units as referred to in paragraph (1) can stand alone which are regulated and managed synergistically by BUMDesa to grow into joint ventures.

- Business units within BUMDesa as referred to in paragraph (1) may carry out joint business activities including:

- Development of large-scale Village ships to organize small fishermen so that their business becomes more expansive;

○ Tourism Village which organizes a series of types of businesses from community groups; and

○ Joint business activities that consolidate other types of local businesses.

Whereas with the provisions, it can lead to a solution to the problems mentioned above. In other words, BUMDesa Mandala Sari is certainly able to embrace several tourism businesses in Bongkasa Pertiwi Village. Before this is done, it is fitting to create a legal instrument that legitimizes BUMDesa Mandala Sari to be able to carry out business governance and be positioned as a holding company. The formation of regulations in the form of the Bongkasa Pertiwi Village Regulation which was formed based on the aspirations of the community according to the Law on Villages will strengthen the role of BUMDesa Mandala Sari as a holding company that oversees the small businesses under it. This institutional strengthening is also a solution to licensing problems that have been difficult to obtain by existing businesses. This management model currently deserves to be developed to facilitate many interests, both from business actors and the government

The position of BUMDesa Mandala Sari as the holding company for the rafting business is expected to be able to solve the problems that have occurred so far, especially those caused by unfair competition which impact on the destruction of the price of the rafting business, which can be resolved by setting the same price by BUMDesa Mandala Sari. Everyone who wants to visit Bongkasa Pertiwi Tourism Village must book a ticket at BUMDesa Mandala Sari. Regulations regarding transactions will be further regulated in ART BUMDesa Mandala Sari as the holding company for the rafting business under it. BUMDesa Mandala Sari will not monopolize the existing business but will keep the business healthy in the business competition which has not been well maintained. Companies or business units that are under BUMDesa Mandala Sari will still have autonomy in managing their own business or business operations. Likewise, in terms of income, they will have separate financial reports from BUMDesa's finances. The pattern of empowerment that can also be carried out by BUMDesa is by conducting trainings for existing tourism actors to improve their capabilities and service quality. 
BUMDesa can work with third parties as part of the empowerment activities in question, such as involving universities in Bali through Community Service activities.

The BUMDesa business unit will supply most of the needs of each business that it will support. Starting from the bottled water provided by BUMDesa, it will also provide other necessities such as soap, towels, even leasing of buoys and rafting equipment. Furthermore, BUMDesa must see other opportunities and potentials that are currently there by also being able to provide benefits to the people of Bongkasa Pertiwi Village. With the potential for independent rice from the village, BUMDesa should make good use of it, in the sense that BUMDesa can package and sell agricultural products native to Bongkasa Pertiwi Village. Furthermore, the existence of vegetables from farmers can also be distributed directly to the businesses under them. Likewise, with the presence of craftsmen in the village, they can be given guidance and channelled into souvenirs typical of Bongkasa Pertiwi Village. This activity certainly has the potential to generate profits for BUMDesa so that it can later support Village Original Income in the future.

BUMDesa has been carrying out its tax obligations appropriately and carefully. Starting in 2018, BUMDesa Mandala Sari already has a NPWP and reports on its tax obligations. This can provide opportunities for the government and local governments in collecting income tax or entertainment tax from these businesses, considering that so far this has not been implemented optimally because they do not have NPWP and NPWPD. For this reason, an approach can be made in the implementation of tax obligations that bind these businesses.

Based on the understanding of the provisions of Article 78 paragraph (1) of Government Regulation Number 72 of 2005 concerning Villages, it states that: BUMDesa as a village economic body which is a legal entity is established and owned by the Village Government, is managed economically independently and professionally with total capital, or most of these are separated village assets, to obtain profits to strengthen Village Original Income, advance the village economy, and improve the welfare of village communities [15]. So, it is fitting for the existence of BUMDesa Mandala Sari to take other strategic steps such as managing business permits that have not been obtained from some of the existing businesses under its auspices. The derivative effect of this business license is how BUMDesa Mandala Sari will indirectly be able to provide legal protection to the people of Bongkasa Pertiwi Village who become workers in the businesses it shelters. This cannot be separated considering that so far workers in this business sector have not received rights protection in the form of income or insurance in the form of BPJS Employment and BPJS Health. The formation of a holding company for the tourism village of Bongkasa Pertiwi can be seen in Figure 1.

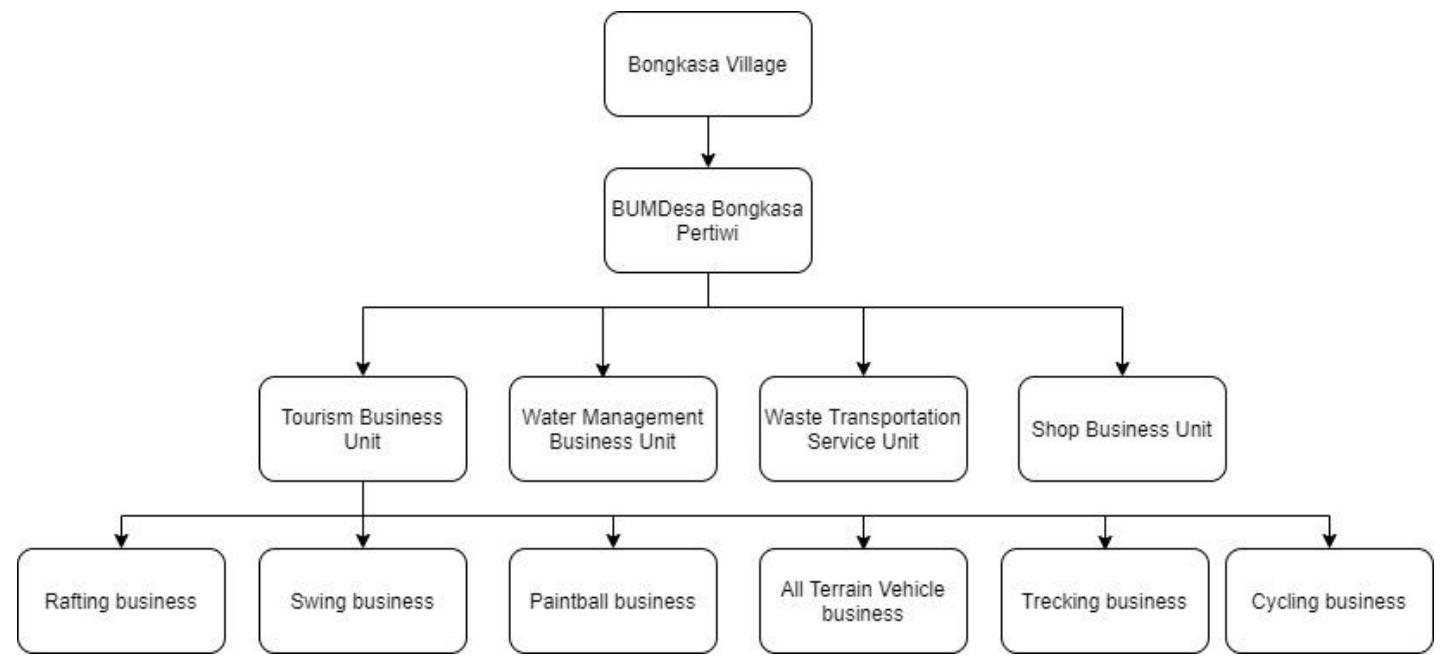

Fig. 1. Establishment of a holding company in Bongkasa Pertiwi Tourism Village.

\section{CONCLUSION}

Based on Article 24 of the Regulation of the Minister of Villages, Development of Disadvantaged Areas and Transmigration Number 4 of 2015, BUMDesa Mandala Sari can become a holding company for businesses such as rafting, atv, swing, paintball and cycling in Bongkasa Pertiwi Village. Strengthening regulations in the form of the Bongkasa Pertiwi Village Regulation in the establishment of BUMDesa Mandala
Sari must be carried out as a continuation of existing regulations on it. This strategic step must be balanced with efforts in developing SME businesses under the auspices of BUMDesa Mandala Sari but eliminating the operational authority of each UKM. BUMDesa can help maintain price stability, which so far has not been guaranteed. Besides being able to help SMEs with empowerment and business development activities by involving third parties, improving 
human resources with trainings, BUMDesa is also expected to be able to provide gality aspects to the businesses it supports in the future. The advantage for BUMDesa can be obtained from this collaboration is that it can sell the goods it sells at BUMDesa shops. Besides, the BUMDesa is plotted to distribute agricultural products from farmers and craftsmen in Bongkasa Pertiwi Village, such as rice, vegetables and handicraft products that can be used as souvenirs for tourists visiting Bongkasa Pertiwi Village. The protection of local workers is a part that must also be handled properly according to existing regulations. The ideal institutional system can be a model for similar tourism villages in Bali Province, so that the goal of establishing BUMDesa will be of optimal benefit to the village community.

\section{ACKNOWLEDGMENT}

The author would like to thank profusely to Bongkasa Pertiwi Tourism Village and P3M Bali State Polytechnic for their support in this research.

\section{REFERENCES}

[1] W. Bhudianto, "Sistem Ekonomi Kerakyatan Dalam Globalisasi Perekonomian,” Transformasi, vol. 14, no.22, pp 1-9.

[2] D.R.I. Hapsari, "Hukum Dalam Mendorong Dinamika Pembangunan Perekonomian Nasional Ditinjau Dari Prinsip Ekonomi Kerakyatan," Legality, pp 238-252.

[3] Surat Keputusan Gubernur Bali No. 570/1665/BPM tentang Penghentian Sementara Pendaftaran Penanaman Modal untuk Bidang Usaha Jasa Akomodasi Pariwisata, 2014.
[4] N.N.S. Wisudawati and A.A.I.A Maheswari, "Potential of Silver Craft Product through to Community-Based for Tourism Sustainability in Celuk Village," International Research Journal of Management, IT \& Social Sciences, vol. 5, no.2, pp 9-15, 2018.

[5] I.W.R. Junaedi and I.G.B.R. Utama, “Agrotourism As The Economics Transformation Of The Tourism Village In Bali (Case Study: Blimbingsari Village, Jembrana, Bali)," Journal of Business on Hospitality and Tourism, vol. 2, no.1, pp 26-40, 2016.

[6] K.A. Astuti and G.S.Darma, "Community-Based Tourism: Measuring Readiness of Artificial Intelligence on Traditional Village," International Journal of Social Sciences and Humanities, vol. 3, no. 3, pp 81-89, 2019.

[7] Peraturan Desa Bongkasa Pertiwi Nomor 5 Tahun 2017 tentang Pendirian dan Pengelolaan Badan Usaha Milik Desa (BUMDesa), 2017.

[8] Sugiyono, Metode Penelitian Pendidikan (Pendekatan Kuantitatif, Kualitatif, dan R\&D) Ed. IX, Bandung: Alfabeta, 2009.

[9] N. Irawan, Tata Kelola Pemerintahan Desa Era UU Desa, Jakarta : Yayasan Pustaka Obor Indonesia, 2017.

[10] Peraturan Menteri Pariwisata dan Kebudayaan Republik Indonesia Nomor: PM.26/UM.001/MKP/2010 tentang Program Nasional Pemberdayaan Masyarakat (PNPM) Mandiri Pariwisata melalui Desa Wisata, 2010.

[11] C. Fandeli, Perencanaan Kepariwisataan Alam. Yogyakarta: Fakultas Kehutanan Universitas Gadjah Mada, 2002.

[12] Peraturan Bupati Badung Nomor 47 Tahun 2010 tentang Penetapan Kawasan Desa Wisata di Kabupaten Badung, 2010.

[13] Peraturan Daerah Provinsi Bali Nomor 2 Tahun 2012 tentang Kepariwisataan Budaya Bali, 2012.

[14] Peraturan Menteri Desa, Pembangunan Daerah Tertinggal dan Transmigrasi Nomor 4 Tahun 2015 tentang Pendirian, Pengurusan dan Pengelolaan, dan Pembubaran Badan Usaha Milik Desa, 2015.

[15] Peraturan Pemerintah Nomor 72 Tahun 2005 tentang Desa, 2005. 